\title{
Growth Characteristics Layur Fish Lepturacanthus savala in Juata Waters, Tarakan, Indonesia
}

\section{Agus Indarjo1,2*, Gazali Salim³ ${ }^{3}$, Fahrizal Amir ${ }^{3}$, Supriadi³, Permana Ari Soejarwo4, Christine Dyta Nugraeni ${ }^{5}$, Lukman Yudho Prakoso ${ }^{6}$, Ambariyanto Ambariyanto ${ }^{1}$, Muhammad Firdaus ${ }^{3}$, Julian Ransangan 7}

${ }^{1}$ Department of Marine Science, Faculty of Fisheries and Marine Science, Diponegoro University Jl. Prof. H. Soedarto, S.H, Tembalang, Semarang, Jawa Tengah 50275, Indonesia

2Directorat Vacation of Indonesian Ministry of Education and and Culture Institutional, Indonesia Jl. Jenderal Sudirman, Senayan, Jakarta Pusat 10270 Indonesia

${ }^{3}$ Department of Aquatic Resource Management, Faculty of Fisheries and Marine Science, Borneo Tarakan University J. Amal Lama No. 1, Tarakan, North Kalimantan, 77115, Indonesia

${ }^{4}$ Research Center for Marine and Fisheries Socio Economics, Ministry of Maritime Affairs and Fisheries Republic of Indonesia Jl. Pasir Putih I, Ancol Timur, Jakarta 14430, Indonesia

${ }^{5}$ Department Technology of Fishery Product, Borneo Tarakan University

Jl. Amal Lama No. 1, Tarakan, North Kalimantan, Indonesia 77115

${ }^{6}$ Department Sea Defense Strategy, Faculty Strategy Defence of Indonesia Defense University

Kawasan IPSC Sentul, Sukahati, Citeureup, Bogor, West Java 16810 Indonesia

7Microbiology and Fish Disease Laboratory, Borneo Marine Research Institute, University Malaysia Sabah

Jalan UMS, 88400 Kota Kinabalu, Sabah, Malaysia

Email: indarjoa@yahoo.com

\begin{abstract}
The city of Tarakan, Indonesia, benefits economically from abundant marine biological resources, one of which is the layur fish, known commercially as ribbonfish. The purpose of this study was to analyze the growth character of the layur fish (Lepturacanthus savala). The method of this quantitative and descriptive study was to analyze the growth of layur fish L. savala in the Juata waters off the coast from the city of Tarakan. Body shape, length, weight, and sex ratio data were collected from sites selected by the purposive sampling method based on trawl fishing catch. Secondary data, collected from interviews of fishing personnel, included the number of catches using trawling gear and trawl fishing location. The length ranges of male from 20,4 to 54,0 cm with an average length of $37,2 \pm 16.8 \mathrm{~cm}(n=255)$ and the length ranges of female from 20,5 to $68 \mathrm{~cm}$ with an average length of $44,25 \pm 23.75$ $\mathrm{cm}(n=275)$. The results showed that maximum length of male layur fish was smaller than the maximum length of female fish, which were $59.352 \mathrm{~cm}$ at $267 \mathrm{~d}$ and $72.638 \mathrm{~cm}$ at $315 \mathrm{~d}$, respectively. The result shows a negative allometric growth pattern male and female layur fish was found to be the same and sex ratio of male to female has a ratio of 1,0: 1,8 with a percentage of males at $48.11 \%$ and females at $51.89 \%$. The majority of male and female fish exhibited a thin body shape (51,4\% of male and $52 \%$ of female).
\end{abstract}

Keywords: Fish Characteristics, Growth Analysis, Bertalanffy Model, body shape

\section{Introduction}

The city of Tarakan is located on the west coast of Tarakan Island, a small landmass off the east coast of North Kalimantan province. Adjacent to the city's coast is an estuarine ecosystem with abundant marine fishery resources, including a wealth of highvalue marine biota, such as nomei and layur fish (Salim et al., 2019). A 2018 report published by the Central Statistics Agency (BPS) in the city of Tarakan stated that the Juanta capture fisheries sector catches 2,145.20 tons annually, contributing significantly to local revenue (BPS, 2018).
The layur fish L. savala has a long, elongated body and is considered bycatch by the trawl fishing industry in the Tarakan area (Salim et al., 2019). Layur fish are caught by trawling gear twice a month at neap tide (Salim et al., 2019) and are widespread in all territorial waters of Indonesia. It is carnivorous and cannibalistic, preying on other fish (Vianita R., 2014), and practices vertical diurnal migration that distinguishes the adult from the juvenile feeding grounds. Generally, the adults forage during the day and migrate to the bottom of the water column at night. It is known commercially as the ribbonfish and has high economic value including that as an export commodity (Bambang, 2018) in increasing demand 
in Taiwan, Korea, Japan, and China (Muhammad et al., 2017). The high demand for layur fish contributes significantly to the capture fisheries sector in Indonesia and has had a positive impact on the economic well-being of the fishing community (Airlangga et al., 2018).

Rachmawati and Hartati (2017) found that layur fish represented $32.90 \%$ of the total annual demersal fishery catch in Pangandaran waters in West Java, but in 2015 they represented $47.31 \%$. Bonte and Firdaus (2012) investigated total fish captured by trap net in Tarakan waters and found 17 total species, only $0.14 \%$ of which were layur fish. The high demand for layur fish leads to potential of overfishing. For sustainable management, more studies on the growth, mortality, and exploitation of the species are necessary (Effendie, 2002). The objective of this research is to analyze the growth of layur fish $L$. savala from Juata waters off the coast of the city of Tarakan using the von Bertalanffy growth model, allometric model, and body shape. The result of this research may be used to predict the maximum length of fish and determine the size of fish allowed to be caught based on the growth period length. The Aim of this research was to analyze the growth character of layur fish ( $L$. savala) in the Juata waters of Tarakan City.

\section{Materials and Methods}

This research was carried out in October 2018-January 2019. A total of 12 sample collection sites were determined using a purposive sampling method of fish caught by trawl fishing. The sampling goal was to collect at least $10 \%$ of the catch is expected to represent the population length, weight, sex, and body shape. Measurements were done to obtain a qualitative description of growth for use in the von Bertalanffy model. In addition, descriptive data regarding layur fish mortality were obtained.

Secondary data were obtained from interviews that included the number of trawl fish catches. Absolute growth was determined using the Von Bertalanffy model (Sparre and Seibren, 1999). Growth parameters were quantified with the maturity level factor using the class mode method attributed to the von Bertalanffy model. The maturity structure variable was used to derive the following linear equation, plotting $\mathrm{L}(\mathrm{t})$ and $(\Delta \mathrm{L} / \Delta \mathrm{t})$. The theoretical age of $L$. savala can be estimated separately with empirical equations when the length is equal to zero (Sparre and Seibren, 1999).

The growth model was used to determine by weight-length relationship. The following is the growth model formula based on characteristics and population index using length and weight data, changed to logarithmic form. A growth model with allometry uses a formula based on Weatherley (1972). Growth method with allometric characteristic uses a formula based on (Lagler, 1961; Effendie, 1979).

\section{Result and Discussion}

\section{Length structure distribution}

The total number of sample measured was 530 fishes, with 255 males (48.11\%) and 275 females (51.89\%). The length of male fish was distributed within 10 classes with the most fish $(93$, or $36.47 \%$ ) in the $31.6+1.5 \mathrm{~cm}$ range, while one fish (0.39\%) was $51.5 \pm 2.5 \mathrm{~cm}$ (Table 1.). Female fish were also categorized, and 93 fish (40.36\%) were $35.15 \pm 2.05 \mathrm{~cm}$, and one fish $(0.36 \%)$ was $64.15 \pm$ $3.85 \mathrm{~cm}$. However, there were two class ranges not found in female fish, representing $53.85 \pm 6.35 \mathrm{~cm}$ (Table 2).

Table 1. Length distribution of male L. savala

\begin{tabular}{ccc}
\hline Length of Fish & Number of Fish & Percentage \\
\hline $20.4-22.4$ & 13 & 5.10 \\
$22.5-24.7$ & 5 & 1.96 \\
$24.8-27.2$ & 11 & 4.31 \\
$27.3-30.0$ & 9 & 3.53 \\
$30.1-33.1$ & 93 & 36.47 \\
$33.2-36.5$ & 76 & 29.80 \\
$36.6-40.2$ & 39 & 15.29 \\
$40.3-44.3$ & 5 & 1.96 \\
$44.4-48.9$ & 3 & 1.18 \\
$49.0-54.0$ & 1 & 0.39 \\
\hline
\end{tabular}

Table 2. Length distribution of female $L$. savala

\begin{tabular}{ccc}
\hline Length of Fish & Number of Fish & Percentage \\
\hline $20.5-23.0$ & 13 & 4.73 \\
$23.1-26.0$ & 4 & 1.45 \\
$26.1-29.3$ & 16 & 5.82 \\
$29.4-33.0$ & 97 & 35.27 \\
$33.1-37.2$ & 111 & 40.36 \\
$37.3-42.0$ & 25 & 9.09 \\
$42.1-47.4$ & 8 & 2.91 \\
$47.5-53.4$ & 0 & 0.00 \\
$53.5-60.2$ & 0 & 0.00 \\
$60.3-68.0$ & 1 & 0.36 \\
\hline
\end{tabular}

\section{Variable absolute growth}

The form of the regression equation differed from other regression equations because the regression equation lines are located on the X-axis. This indicates the growth of males was at a maximum at zero on the $\mathrm{Y}$-axis. The $\mathrm{X}$-axis represents the growth rate and the $\mathrm{Y}$-axis represents the length. The 
regression equation obtained using the growth speed and length of males was $y=-0.051 x+3.0254$ with a correlation value of 0.5587 (55.87\%). The regression equation is used to obtain maximum growth where the formula is $-a / b$. The maximum growth was $59.332 \mathrm{~cm}$. The value of $\mathrm{b}$ explains the growth rate using formula $-b$. The growth rate was $0.051 \mathrm{~cm}$.day1 (Figure 1.). The value of $a$ is constant.

Figure 1 demonstrates the von Bertalanffy model based on the growth speed and length relationship of males, showing the maximum growth in males was $59.332 \mathrm{~cm}$ with an average daily growth rate of $0.051 \mathrm{~cm}$.day-1. The average daily growth was obtained using formula $-b$. This is in accordance with Effendie (1997) in which fish growth was autocatalytic when a growth rate is zero, then there is no future length growth.

According to Firdaus and Salim, (2013); Gazali Salim, (2015); Salim and Kelen, (2018); Indarjo et al., (2020); Firdaus et al. (2020), the regression line in
Figure 1 and 2 explains that to get the maximum growth $(L \infty)$ and the speed of growth coefficient based on the regression equation $y=a+b x$ using the formula of Sparre and Seibren (1999) that is the average length-model value (- a / b) is used to assess the asymptotic length $(L()$ using the linear regression method, while the growth coefficient $(K)$ is $-b$. Correlation values obtained in the regression equation are used to analyze two different variables between the total length and total weight of layur fish (L. savala) using correlation criteria based on (Sarwono, 2006). According to Sarwono (2006) if the correlation value is zero then there is no correlation value; if the correlation value between $>0-0.25$ has a very weak correlation value; if the correlation value between> 0.25-0.50 has a weak correlation value; if the correlation value between $>0.5-0.75$ has a Sufficient correlation value; if the correlation value between> 0.75-0.99 has a very strong correlation value and if the correlation value 1 has a perfect correlation value.

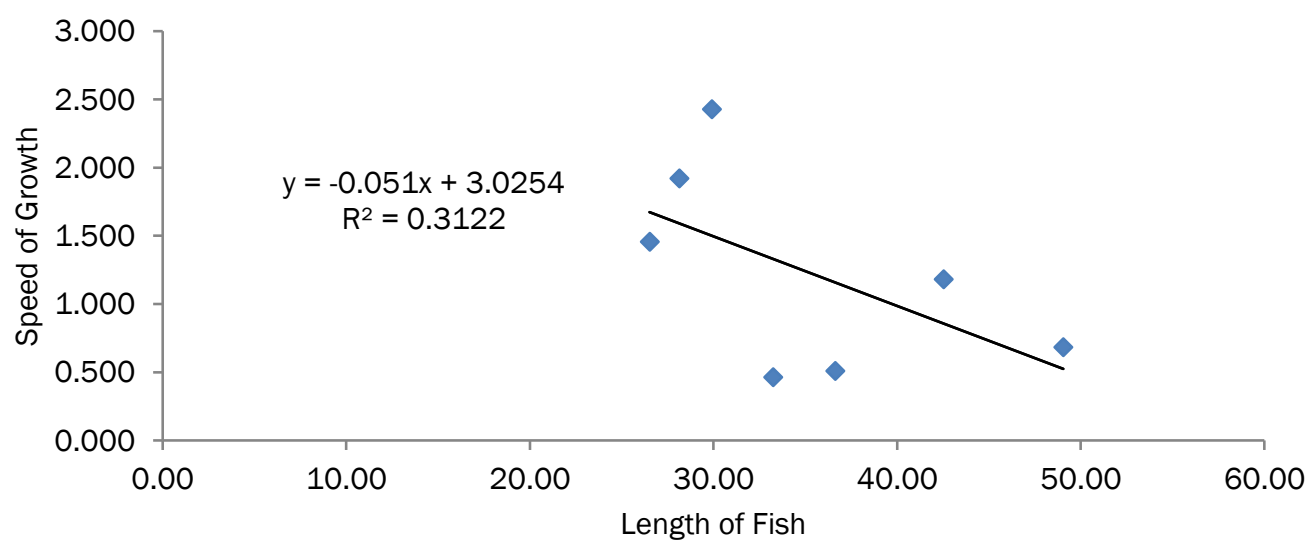

Figure 1. The von Bertalanffy model based on the growth rate and length relationship of male fish Lepturacanthus savala

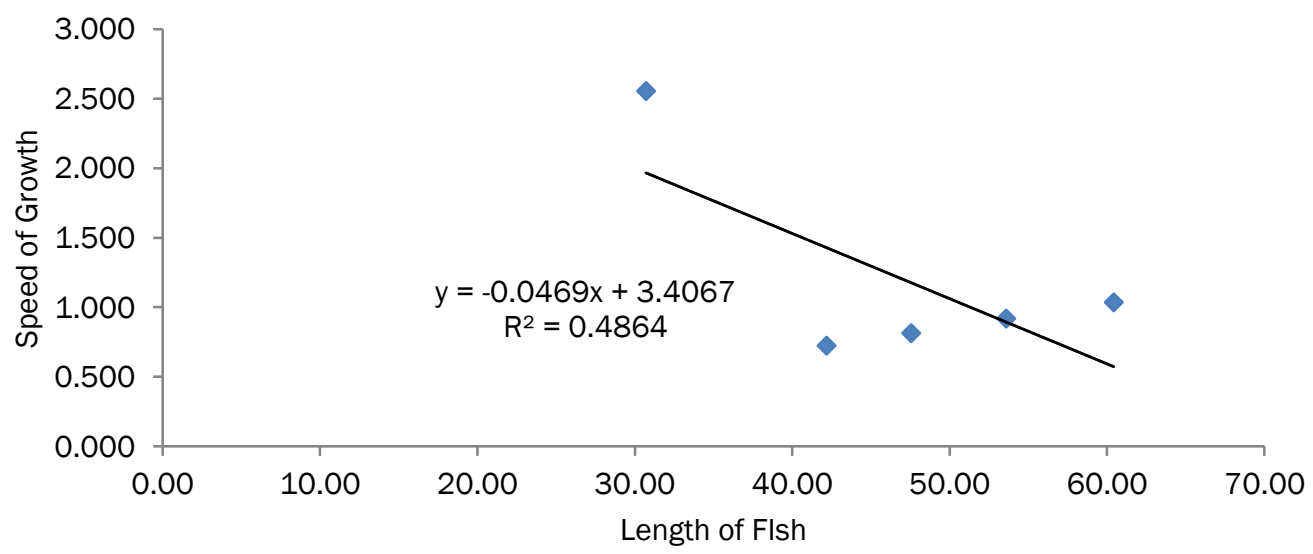

Figure 2. The von Bertalanffy model based on growth rate and length relationship of female fish Lepturacanthus savala 
Figure 2 demonstrates the von Bertalanffy model of the growth (X-axis) and length (Y-axis) of females. The regression equation is $y=-0.0469 x+$ 3.4067 with a correlation value of 0.6974 (69.74\%). As the regression equation line reached the $X$-axis, the growth of females reached a maximum with a growth speed of zero on the Y-axis. The von Bertalanffy growth equation describes the lifetime pattern of somatic growth and the growth of an exploited fish population. There are two separate equations. A pre-maturity equation, in which all energy is used towards somatic growth and a postmaturity equation, in which all or some energy is used for reproduction. The age at maturity is a parameter of somatic growth provided in the growth equation. The asymptotic curve demonstrates that all or some energy is devoted to reproduction. The linear curve shows that all energy is used for somatic growth (Lester et al., 2004).
Based on the von Bertalanffy model formula, the maximum length growth of females (Figure 2.) shows the average daily growth rate of 0.0469 $\mathrm{cm}$ day $^{-1}$ with the maximum length growth of 72.638 $\mathrm{cm}$. The growth equation of males, obtained by using the orthogonal polynomial type 6 of Von Bertalanffy model, was $y=-7 \mathrm{E}-12 \mathrm{x}^{6}+7 \mathrm{E}-09 \mathrm{X}^{5}-3 \mathrm{E} 06 \mathrm{X}^{4}+$ $0.0005 X^{3}-0.0481 X^{2}+2.5136 X+4.4493$ with $a$ correlation value of $0.99975(99.975 \%)$. Figure 3 demonstrates that males at age zero are approximately $3.652 \mathrm{~cm}$ in length. Fish obtained from trawl catches were $37.2 \pm 16.8 \mathrm{~cm}$. The smallest captured male was $20.4 \mathrm{~cm}$ at age $8 \mathrm{~d}$. The age can be obtained using the von Bertalanffy model formula. The largest captured male was $54 \mathrm{~cm}$ at age $51 \mathrm{~d}$, but this was not the maximum length in the growth model (59.332 cm, at age $267 \mathrm{~d}$. Ahmad (2008) noted that the maximum length of layur fish in Palabuhan Ratu, West Java was $125 \mathrm{~cm}$ at age $8 \mathrm{y}$, representing a growth rate of $13.94 \mathrm{~cm} . \mathrm{y}^{-1}$.

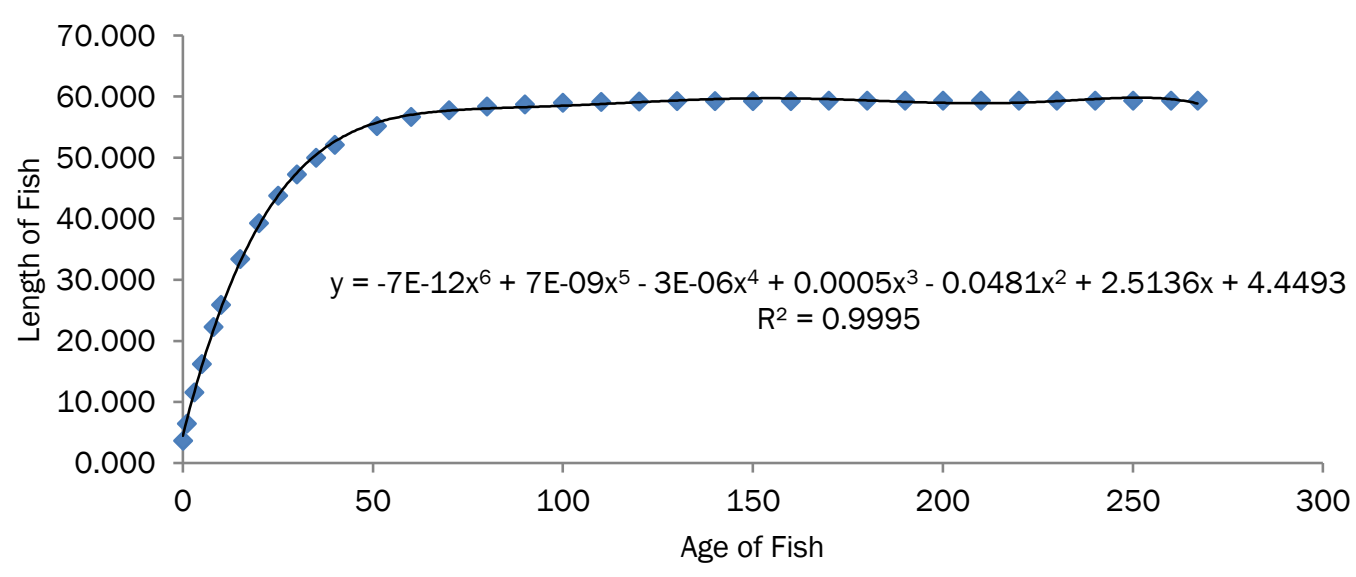

Figure 3. Polynomial orthogonal type 6 of von Bertalanffy model in male fish Lepturacanthus savala

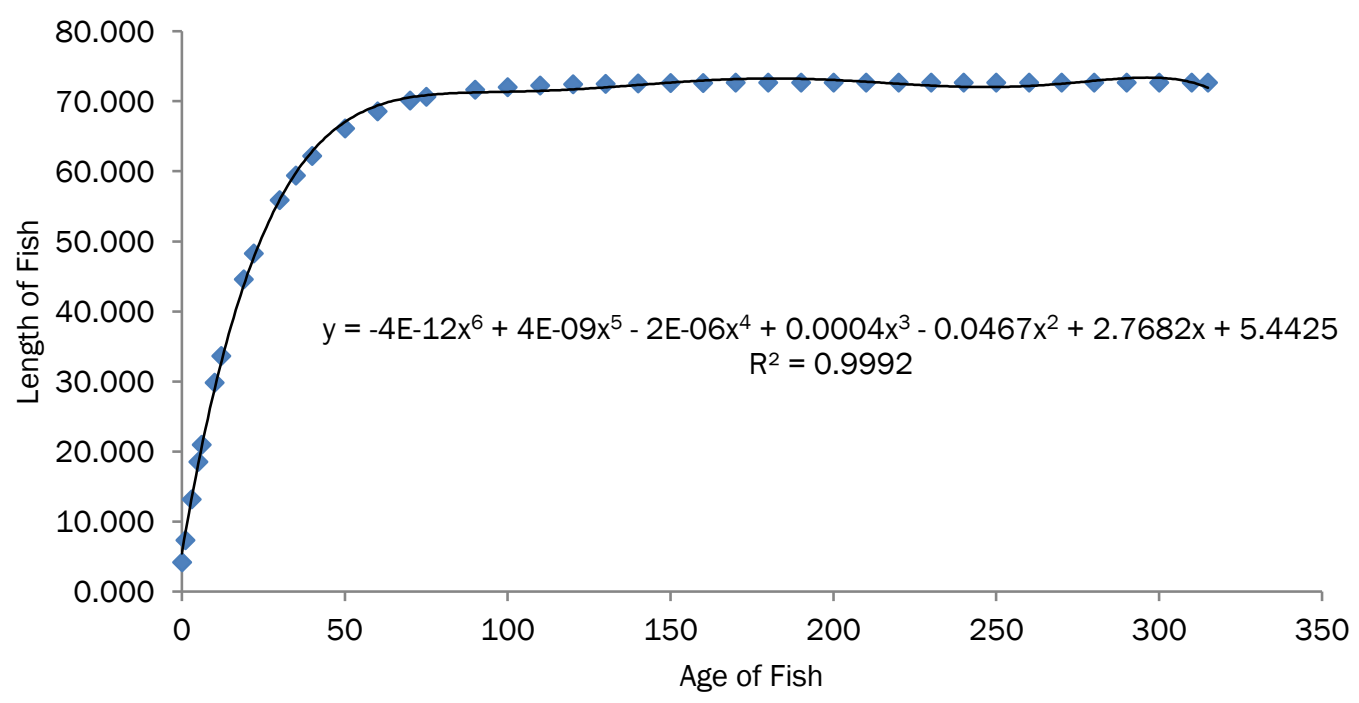

Figure 4. Polynomial orthogonal type 6 of Von Bertalanffy Model in female fish Lepturacanthus savala 
The growth regression equation of female Layur fish determined using von Bertalanffy model was $\mathrm{y}=-4 \mathrm{E}-12 \mathrm{X}^{6}+4 \mathrm{E}-09 \mathrm{X}^{5}-2 \mathrm{E}-06 \mathrm{X}^{4}+0.0004 \mathrm{X}^{3}-$ $0.0467 X^{2}+2.7682 X+5.4425$ with a correlation value of 0.9996 (99.96\%). Figure 4 shows that females at age $0 \mathrm{~d}$ were $4.167 \mathrm{~cm}$, while the maximum length of females was $72.638 \mathrm{~cm}$. The trawl catch of females was 20.5-68 cm (44.25 \pm $23.75 \mathrm{~cm})$. The smallest size of female fish was reached at approximately $6 \mathrm{~d}$ and the largest size was approximately $58 \mathrm{~d}$; however, according to the model, females can reach a maximum length of $72.638 \mathrm{~cm}$ at 315 d. According to Rizvi and Deshmukh (2003) reported the maximum length and age of a related species, L. savala from Mumbai, India waters was $64.0 \mathrm{~cm}$ at $3.3 \mathrm{y}$. This is in accordance with the finding of (Rachmawati and Hartati, 2017) where in Pangandaran waters of Analysis of fish ( $L$. savala) population parameter obtained asymptotic total length $(T L)=111,00 \mathrm{~cm}$, growth rate $(K)=0,56 \cdot y^{-1}$. According to Nazrul et al. (2018) in major fish landing centers of south-east Bangladesh where The asymptotic length $L$. savala $(L \infty)=111 \mathrm{~cm}$ and growth coefficient (k) $0.34 y^{-1}$. According to Memon et al (2016) explain growth population fish of $L$. savala in Pakistan waters were $L \infty 133.35 \mathrm{~cm}$ and $k=0.130 \mathrm{y}^{-1}$. Agustina et al. (2016) explain that fish of L. savala landed in Labuan Banten with a fishing ground from the Sunda Strait waters, has the results asymptotic length (Lo) $710,41 \mathrm{~mm}$ for females and $856,52 \mathrm{~mm}$ for males and value of the growth coefficient $(k)$ for female and male were 0,30. mon $^{-1}$ and 0,23. mon $^{-1}$ respectively.

\section{Variable length-weight relationship}

The relationship between the length and weight of male fishes was $y=1.237 x-0.5824$. The value of $b$ in the regression equation is 1.237 (Figure 5a.). While the relationship between the length and weight of females was $y=1.3557 x-0.7668$ (Figure $5 b$.$) with a correlation value of 0.6324$ (63.24\%).

The relationship between the length and weight of male fishes was $y=1.237 x-0.5824$, with a correlation value of 0.5821 (58.21\%). The value of $b$ in the regression equation is 1.237 (Figure 5a.). Effendie (1979) considers the growth allometrically negative if the value of $b<3$. This indicates that the growth of males was faster in length than in body weight. While the relationship between the length and weight of females was $y=1.3557 x-0.7668$ (Figure $5 b$.$) with a correlation value of 0.6324$ (63.24\%). The value of $b$ of the regression equation was 1.3557
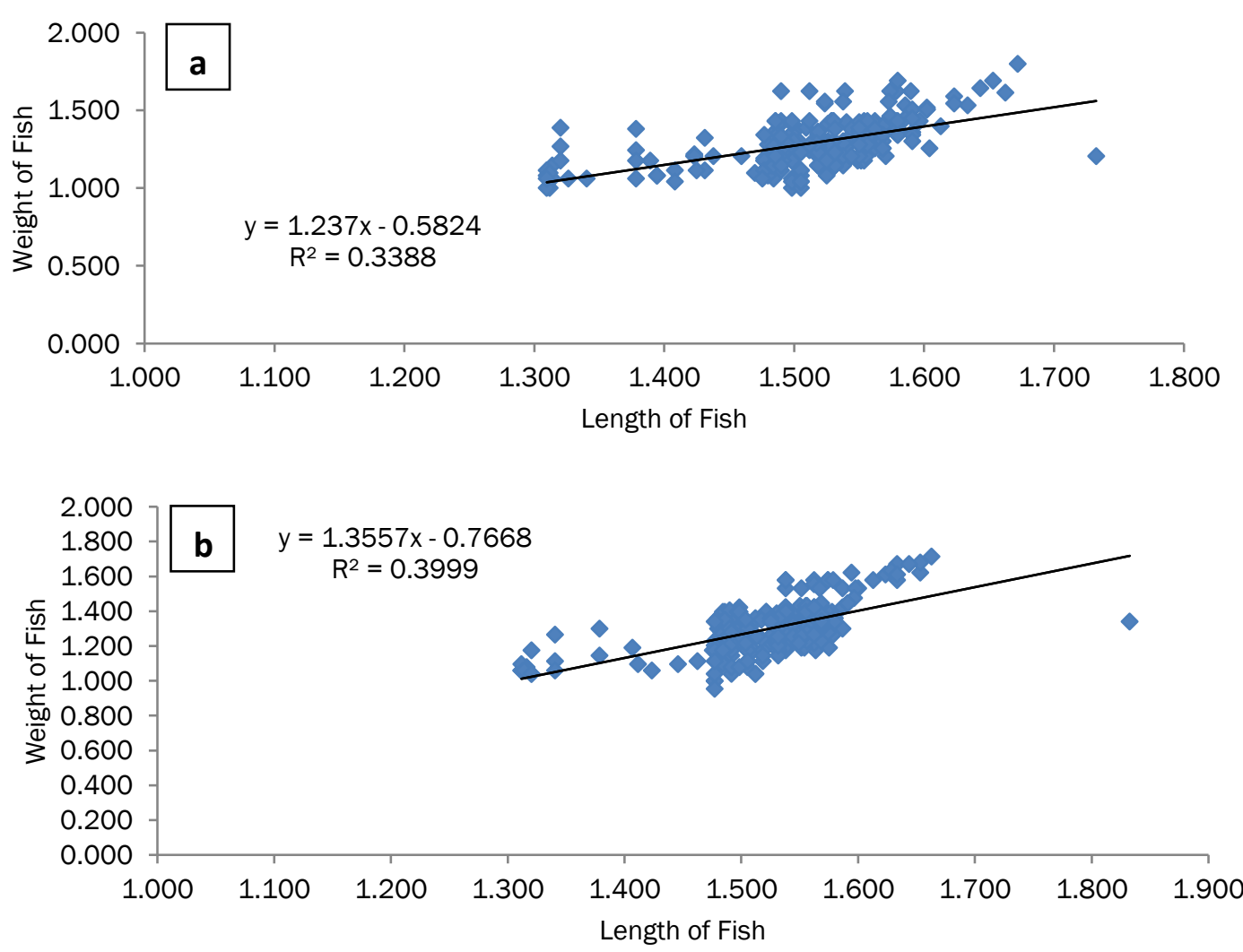

Figure 5. Length and weight relationship of male (a) and female (b) fish Lepturacanthus savala 
(Figure 5b), which indicates a lack of allometric growth (Effendie, 2002). The growth in length of females was faster than in body weight.

This is in accordance with the finding of (Rachmawati and Hartati, 2017) where in Pangandaran waters of Analysis of fish (L. savala) has the result shows a negative allometric growth pattern $(b=2,92)$. However this differs from the Pakistan waters in 2009-2010 explained that the estimated values of length-weight relationship for L.savala were $b=3.191\left(R^{2}=0.960\right) n=1391$ (Positive-Allometry). Pakhmode et al. (2013) explained that the L. savala fish found off the Ratnagiri coast obtained a value of $b=3.2285$ with positive allometric growth.

\section{Male and female fish body condition}

Among 255 male fish, there were four body shapes: very thin (0.4\%), thin (51.4\%), fat (40.8\%), and very fat $(7.5 \%)$ (Table 3.). In January 2019, fish were generally thin. This is consistent with Effendie (1997), in which November-December is a transition season between the east and west, causing an increase in water temperature whereby energy is used to adapt to the fluctuating aquatic environment, so most layur fish were likely actively foraging during that time. Environmental factors influence fish body shapes (Salim, 2013; 2015; Firdaus et al., 2018).

Among 275 female fish, there were five body shapes obtained: very thin $(0.4 \%)$, thin $(52 \%)$, ideal (1.1\%), fat (40\%), and very fat (6.5\%) (Table 3.). This indicates that females had less body fat than males, likely because derived energy from food in female fish was used towards reproduction and energy was distributed to the eggs (Effendie, 2002).

Table 3. Number (\%) of Male and Female Fish Lepturacanthus savala with Different Body Shape

\begin{tabular}{crc}
\hline Body Shape & Male & Female \\
\hline Very thin & 0.4 & 0.4 \\
Thin & 51.4 & 52.0 \\
Ideal & 0 & 1.1 \\
Fat & 40.7 & 40.0 \\
Very fat & 7.5 & 6.5 \\
\hline
\end{tabular}

\section{Conclusion}

The results obtained that the sex ratio of male and female layur fish (L.savala) was 1: 1.08 with a percentage of males at $48.11 \%$ and females at $51.89 \%$. Absolute growth using the Von Bertalanffy model for infinitive growth of layur fish was 59.332 $\mathrm{cm}$ with a growth rate of $0.051 \mathrm{~cm} . \mathrm{d}^{-1}$ for 267 days and female L.savala of $72.638 \mathrm{~cm}$ with a growth rate of $0.0469 \mathrm{~cm} . \mathrm{d}^{-1}$ for $315 \mathrm{~d}$. The growth of male and female layur fish (L.savala) is negative allometri with correlation values ranging of $0.607 \pm 0.025$ (moderate). The growth model of the male layur (L.savala) condition index has a thin body shape of $51.4 \%$ and a fat body shape of $40.8 \%$, while a female layur fish has a thin body shape of $52 \%$, a fat body shape of $40 \%$.

\section{Acknowledgment}

The authors thank to Supriadi NPM 13.101020.033 and Fahrisal Amir NPM 14.101020.026 in the Department of Aquatic Resources Management FPIK UBT-Kaltara as one of the Final Project part and government agencies in Tarakan City such as the Maritime and Fisheries Agency Tarakan City, BPS Tarakan City, as well as Trawl fishing gear fishermen in Juata waters Tarakan city who have provided information to support this research.

\section{References}

Agustina, S., Boer, M. \& Fahrudin, A. 2015. Dinamika Populasi Sumber Daya Ikan Layur (Lepturacanthus savala) Di Perairan Selat Sunda. Mar. Fish. 6(1):77-85. doi: 10.29244/jmf.6.1.77-85

Ahmad, Y. 2008. Model Pertumbuhan Ikan Layur (Trichiurus lepturus Linnaeus, 1758) di Palabuhan Ratu, Jawa Barat. J. Agrosci. 1(1): 111

Airlangga, A., Boer, M. \& Zairion, Z. 2018. Ecosystem Approach to Largehead hairtail (Trichiurus lepturus (Linnaeus , 1758 )) Management at Palabuhanratu Bay, J. Sosial Ekonomi Kel. Perikan. 13(1): 1-13. doi: 10.15578/jsekp.v13 i1.6761

Bonte, S.B. \& Firdaus, M. 2012. Perbedaan Soaking Time terhadap Hasil Tangkapan pada Perikanan Tugu (Trap Net) di Perairan Timur Kota Tarakan, J. Harpodon, 5(2): 147-159

BPS Kota Tarakan. 2018. Kota Tarakan Dalam Angka. 2018. Tarakan: BPS Kota Tarakan.

Effendie, M.I. 1979. Metode biologi perikanan, Yayasan Dewi Sri. Bogor.

Effendie, M.I. 2002. Biologi Perikanan, Yayasan Pustaka Nusatama. Yogyakarta.

Firdaus, M., Salim, G., Cahyadi, J., Weliyadi, E. \& Bintoro, G., 2020. Model and nature of growth of 
red snapper fish (Lutjanus argentimaculatus (Forsskål, 1775)) fishing catch of bottom fish pots in Bunyu waters, North Kalimantan. AACL Bioflux. 13(3): 1410-1421

Firdaus, M., Lelono, T.D., Saleh, R., Bintoro, G. \& Salim, G., 2018. The expression of the body shape in fish species Harpadon nehereus (Hamilton, 1822) in the waters of Juata Laut, Tarakan city, North Kalimantan. AACL Bioflux, 11(3):613-624.

Firdaus, M. \& Salim, G. 2013. Mengkaji Faktor Kondisi Ikan Puput (Ilisha elongata) yang berasal dari perairan Juata, J. Harpodon, 6:2935

Indarjo, A., Salim, G., Zein, M., Susiyanti, S., Soejarwo, P.A., Nugraeni, C.D., Bija, S., \& Pham, Y.T.H., 2020. Characteristics of Von Bertalanfy Growth, Allometric, Condition Index And Mortality of Periophthalmus barbarus in Mangrove and Probiotics Conservation Area (KKMB), Tarakan, North Kalimantan. ILMU KELAUTAN: Indo. J. Mar. Sci. 25(1):31-38. doi: 10.14710/ik.ijms.25.1.31-38

Lagler, K.R. 1961. Article orienting apparatus. Google Patents.

Lester, N.P., Shuter, B.J. \& Abrams, P.A. 2004. Interpreting the von Bertalanffy model of somatic growth in fishes: the cost of reproduction, Proc. Royal Soc. London. Ser. B: Biolog. Sci., 271(1548):1625-1631. doi: 10.1098/rspb.2004.2778.

Memon,K.H., Liu, Q., Kalhoro, M.A., Chang, M.S., Baochao. L., Memon, A.M., Hyder, S. \& Tabassum, S. 2016. Growth and Mortality Parameters of Hairtail Lepturacanthus savala from Pakistan Waters. Pakistan J. Zool. 48(3): 829-837, 2016.

Muhammad, A.A., Farooq, S., Rabbaniha, M., Jahangir, S., Malik, A., Hameed, A. \& Baloch, A.J. 2017. Current fishery status of ribbonfish Trichiurus lepturus Linnaeus, 1758 (Trichiuridae) from Makran coast (northeast Arabian Sea), Iran. J. Fish. Sci. 16(2):815-821.

Nazrul., K.M.S., Al-Mamun, M.A., Suman, B, \& Md. Uddin, S. 2018. Population Dynamics Study of Ribbonfish, Lepturacanthus savala from the North-Eastern Tip of Bay of Bengal. Global J. Sci. Frontier Res.: E Mar. Sci. 18(1):41-47
Bambang, A.N. 2018. Fish Marketing of Ribbon Fish (Trichiurus sp.) in Nusantara Fishing Port (NFP)at Palabuhanratu, West Java, E3S Web Conferen. 31:08012. doi: 10.1051/e3sconf/ 20183108012.

Pakhmode, P.K., Mohite, S.A., Naik, S.D. \& Mohite, A.S. 2013. Length frequency analysis and length-weight relationship of ribbonfish, Lepturacanthus savala (Cuvier, 1829) off Ratnagiri coast, Maharashtra. Int. J. Fish. Aqua. Stud. 1(2): 25-30.

Rachmawati, P.F. \& Hartati, S.T. 2017. Aspek Biologi Ikan Layur (Lepturacanthus savala Cuvier, 1829) Di Perairan Pangandaran, Jawa Barat. Bawal, 9(2): 133-143. doi: 10.15578/bawal.9. 2.2017.133-143.

Rizvi, A.F. \& Deshmukh, V.D. 2003. Growth Parameters of Lepturacanthus savala (Cuvier, 1829) from Mumbai Waters, J. Indian Fish. Assoc., 30: 81-89.

Salim, G. 2013. Nilai indeks kondisi dari ikan siganus javus berdasarkan hasil tangkapan nelayan di Perairan Juata Kota Tarakan, J. Harpodon, 8(1):37-42. doi: 10.35334/harpodon.v6i1.99

Salim, G. 2015. Analisis Pertumbuhan Allometri dan Indeks Kondisi Caesio cunning Didapatkan dari Hasil Tangkapan Nelayan Kota Tarakan, J. Harpodon, 8(1):35-42. doi: 10.35334/ harpodon.v8i1.125

Salim, G. 2019. Kajian Aspek Pertumbuhan Dan Rasio Kelamin Ikan Layur (Lepturacanthus savala) Di Perairan Juata Laut Kota Tarakan, Seminar Nasional Humaniora dan Saintek Universitas Borneo Tarakan.

Salim, G. \& Kelen, P.B. 2018. El Von Bertalanffy and Mortality from Fish Kurau (Polynemus taenitatus) of The Catch Fisherman in Waters Bunyu, Insist. doi: 10.23960/ins.v3i2.165.

Sarwono, J. 2006. Metode penelitian kuantitatif dan kualitatif. Graha ilmu.

Sparre, P. \& Seibren, C.V. 1999. Introduksi Pengkajian Stok Ikan Tropis Buku-I Manual. Kerjasama Organisasi Pangan dan Perserikatan Bangsa-Bangsa dengan Pusat Penelitian dan Pengembangan Perikanan. Jakarta: Badan Penelititan dan Pengembangan Pertanian. 
ILMU KELAUTAN: Indonesian Journal of Marine Sciences September 2020 Vol 25(3):127-134

Vianita R. 2014. Aspek Biologi Layur (Trichiurus lepturus) Berdasarkan Hasil Tangkapan di PPP Morodemak, J. Maquares, 3(3):160-167.
Weatherley, A.H. 1972. Growth and Ecology of Fish population. New York: Academic Press. 